\title{
Pemberdayaan masyarakat melalui pengolahan sampah anorganik menjadi barang dekoratif bernilai ekonomis
}

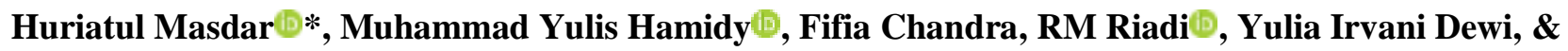 \\ Nurfi Pratiwi
}

Universitas Riau

*huriatul.masdar@gmail.com

\begin{abstract}
Abstrak. Sampah merupakan hasil sisa dari setiap aktivitas sehari-hari manusia yang dibuang yang apabila tidak dikelola dengan baik dapat menimbulkan masalah lingkungan dan kesehatan. Salah satu bentuk pengelolaan sampah yang dilakukan oleh masyarakat adalah melalui bank sampah. RW 08 Kelurahan Air Putih telah memiliki bank sampah yang aktif beroperasi namun kegiatannya masih hanya berkisar pada pengumpulan sampah dari nasabah dan menjual ke pengepul. Untuk meningkatkan nilai dari sampah anorganik yang dikelola, dilakukan pelatihan menghias barang bekas dengan menggunakan teknik decoupage dengan peserta pengelola bank sampah dan ibu-ibu PKK di RW tersebut. Selain itu juga diajarkan bagaimana memanfaatkan media sosial sebagai media pemasaran. Hasil kegiatan menunjukkan tercapainya keterampilan dan kemandirian masyarakat target dalam membuat sampah anorganik menjadi barang dekoratif yang bernilai ekonomi lebih tinggi. Sementara itu, keberlangsungan produksi dan dampak ekonomi yang ditimbulkan dari kegiatan masih membutuhkan evaluasi lebih lanjut.
\end{abstract}

Kata kunci: Bank sampah, sampah anorganik, pemberdayaan masyarakat, decoupage.

Abstract. Garbage is the leftover product from every human daily activity that is thrown away which, if not managed properly, can cause environmental and health problems. Waste bank is a form community participation in waste management. Air Putih Sub-dsitrict already has a waste bank that is actively operating. However its activities are still limited to collect inorganic waste from customers and sell it to collectors. In order to increase the value of inorganic waste collected in the waste bank, a training to decorate used items using decoupage technique was conducted. Waste bank managers and Empowerment Family Welfare (PKK) members were participated in this training. In addition, a training how to use social media as a marketing media were performed. The results showed that the target community's skills had been achieved in processing inorganic waste into decorative items with higher economic value. Meanwhile, the sustainability of production and the economic impact resulting from these trainings still require further evaluation.

Keywords: Waste bank, inorganic waste, community empowerment, decoupage

To cite this article: Masdar, H., M. Y. Hamidy., F. Chandra., RM Riadi., Y. I. Dewi., \& N. Pratiwi. 2020.

Pemberdayaan masyarakat melalui pengolahan sampah anorganik menjadi barang dekoratif bernilai ekonomis.

Unri Conference Series: Community Engagement 2: 222-227. https://doi.org/10.31258/unricsce.2.222-227

(C) 2020 Authors

Peer-review under responsibility of the organizing committee of Seminar Nasional Pemberdayaan Masyarakat 2020 


\section{PENDAHULUAN}

Organisasi Kesehatan Internasional atau World Health Organization (WHO) telah mendefinisikan sampah merupakan hasil dari aktivitas sehari-hari manusia yang tidak lagi digunakan, tidak dipakai bahkan tidak disenangi dan tidak terjadi dengan sendirinya. Dari definisi tersebut dapat disimpulkan bahwa setiap kegiatan manusia sehari-hari akan menghasilkan sisa dalam bentuk sampah. Masyarakat seringkali menganggap sampah sebagai barang yang tidak lagi bernilai ekonomis sehingga diabaikan (Susilowati, 2014; Subekti, 2018). Makin tinggi aktivitas dan konsumsi masyarakat, maka makin tinggi pula sampah yang dihasilkan. Hal ini akan berdampak terhadap buruk terhadap lingkungan dan kesehatan masyarakat, terlebih lagi bila tidak diimbangi dengan pengelolaan sampah yang baik (Riswan et al, 2011).

Pengolahan sampah yang dinilai efektif, terutama pengolahan sampah yang dihasilkan rumah tangga, adalah melalui pemberdayaan masyarakat dengan metode Community Based Participation. Bentuk partisipasi masyarakat ini dimulai dari pemilahan sampah organik dan anorganik, mengolah sampah menjadi barang yang dapat berguna kembali, hingga pembentukan bank sampah di kelola secara mandiri oleh masyarakat dengan jumlah nasabah aktif yang terus meningkat (Mardhia \& Wartiningsih, 2018).

Selain itu, pendekatan Asset Based Community Development (ABCD) yang pertama kali dikenalkan oleh John McKnight dinilai efektif dalam menyelesaikan masalah yang yang ada di masyarakat termasuk dalam hal pengelolaan sampah. Aset yang dapat diidentifikasi dalam hal ini antara lain aset manusia, aset fisik, aset alam, aset sosial dan aset finansial (Susilawati et al, 2018). Metode ini telah diterapkan dalam mengelola sampah di pesisir Bulu Kumba. Meskipun terkendala dengan kuantitas masyarakat target, hasil pelatihan menunjukkan adanya perubahan perilaku masyarakat target dalam mengelola sampah rumah tangga yang dihasilkan (Mallapiang et al, 2020).

Kota Pekanbaru telah memiliki kebijakan pengelolaan sampah yang tertuang dalam Peraturan Daerah Nomor 8 Tahun 2014. Peraturan ini diterbitkan dengan maksud memberikan hak-hak masyarakat untuk mendapatkan lingkungan yang baik dan sehat. Sebagai pihak yang berwenang dalam pengelolaan sampah di Kota Pekanbaru, Dinas Lingkungan Hidup dan Kebersihan Kota Pekanbaru memiliki tugas dalam pengelolaan sampah termasuk mengkoordinasikan, membina serta merumuskan kegiatan penanganan sampah di Kota Pekanbaru termasuk membina pembentukan bank sampah.

Kelurahan air putih merupakan salah kelurahan yang berada di kecamatan tampan kota pekanbaru. Kecamatan tampan ini merupakan kecamatan dengan jumlah penduduk terbanyak dan menghasilkan sampah terbesar per tahunnya. Data statistik menunjukkan total sampah yang diproduksi di kecamatan ini mengalami peningkatan dari 33,82 ton pada tahun 2010 menjadi 94,10 ton per hari pada tahun 2015 seiring dengan peningkatan jumlah penduduk. Jumlah sampah yang dihasilkan tersebut sedikit menurun pada tahun 2016 menjadi 76,85 ton per hari. Penurunan ini bukan diakibatkan oleh turunnya jumlah sampah yang dihasilkan namun dikarenakan berubahnya kebiasaan masyarakat yang membuang sampah tidak pada tempat pembuangan sampah (tps) yang resmi, namun pada tps liar. Selain itu dilaporkan sekitar 1260 ton limbah plastik dihasilkan setiap bulannya (Anggoro fb, 2017).

Saat ini di kelurahan air putih terdapat satu bank sampah yaitu bank sampah berkah yang berada di rw 8 yang merupakan bank sampah binaan fakultas kedokteran universitas riau. Bank sampah ini dibentuk pada tahun 2019 dan masih aktif beroperasi hingga saat ini. Nasabah bank sampah ini sudah mencapai puluhan warga yang berasal dari ke-4 rt yang ada di rw 8 kelurahan air putih tersebut. Kegiatan bank sampah berkah hingga saat ini lebih pada tahap pengumpulan sampah anorganik bersih dari nasabah bank sampah. Sampahsampah tersebut kemudian langsung dijual kepada pengepul sehingga harga jualnya juga masih terbilang rendah. Apabila sampah anorganik tersebut diolah kembali menjadi barang yang dapat digunakan, tentu akan memberikan nilai ekonomis yang lebih tinggi. Mengingat adanya potensi aset yang dimiliki oleh rw 08 kelurahan air putih tersebut, maka perlu dilakukan kegiatan pemberdayaan masyarakat di rw 08 kelurahan air putih dalam pengelolaan sampah secara mandiri. Dengan demikian diharapkan dapat menghasilkan produk yang dapat digunakan kembali dan bernilai ekonomi yang lebih tinggi.

\section{METODE PENERAPAN}

Secara garis besar, pelaksanaan kegiatan ini dibagi menjadi tiga tahap yaitu tahap persiapan, tahap pelaksanan dan tahap monitoring dan evaluasi. Masyarakat target dalam kegiatan ini adalah masyarakat RW 08 Kelurahan Air Putih. Dalam pelaksanaan kegiatan, tim pengabdian bersinergi dengan mahasiswa Kuliah Kerja Nyata Universitas Riau yang ditempatkan di Kelurahan Air Putih tersebut. 


\section{Tahap persiapan}

Pada tahap ini dilakukan identifikasi aset yang telah dimiliki oleh RW 08 Kelurahan Air Putih. Proses identifikasi ini dilaksanakan melalui observasi, sosialisasi dan diskusi dengan aparatur pemerintah daerah, mulai dari Lurah Kelurahan Air Putih, Ketua RW 08, Ketua RT yang ada di RW 08 serta pengelola Bank Sampah Berkah. Hasil kegiatan ini menjadi dasar jenis pelatihan yang akan diberikan dalam rangka mengoptimalkan pemberdayaan masyarakat dalam pengelolaan sampah di RW 08 Kelurahan Air Putih tersebut. Selanjutnya dilakukan penyiapan materi pelatihan serta bahan-bahan yang akan digunakan dalam pelatihan.

\section{Tahap pelaksanaan}

Kegiatan ini dilaksanakan dalam 2 tahap. Pada tahap pertama dilakukan pelatihan pembuatan barang dekoratif dari sampah anorganik dengan mengaplikasikan teknik decoupage. Tahap kedua adalah pelatihan pemasaran produk dengan memanfaatkan media sosial.

\section{Tahap monitoring dan evaluasi kegiatan}

Tahap ini dilaksanakan secara berkesinambungan untuk mengetahui apakah sasaran kegiatan telah tercapai. Ketercapaian sasaran kegiatan dinilai melalui indikator ketercapaian sasaran jangka pendek dan jangka panjang. Adapun indikator ketercapaian sasaran kegiatan jangka pendek yaitu adanya pengetahuan dan keterampilan masyarakat target dalam mengaplikasikan teknik decoupage dengan memanfaatkan sampah anorganik serta pengetahuan dan keterampilan dalam pemanfaatan media sosial secara efektif sebagai media pemasaran. Indikator ketercapaian sasaran kegiatan jangka panjang yaitu adanya keberlangsungan dan kemandirian masyarakat target dalam menghasilkan produk dari olahan sampah anorganik menjadi barang dekoratif serta raihan pasar yang luas.

\section{HASIL DAN KETERCAPAIAN}

Kegiatan pengabdian kepada masyarakat ini telah dilakukan pada bulan agustus dan september 2020 bertempat di rw 08 kelurahan air putih kecamatan tampan. Selama kegiatan, penerapan protokol kesehatan dalam mencegah penularan covid-19 telah dilaksanakan termasuk menghindari pengumpulan masyarakat dalam jumlah besar. Jumlah masyarakat target pada kegiatan ini sebanyak 10 orang yang terdiri dari 6 orang pengelola bank sampah dan 4 orang perwakilan pkk masing-masing rt. Pembatasan jumlah masyarakat target ini diiringi dengan upaya mengoptimalkan capaian sasaran kegiatan.

\section{Identifikasi Potensi Aset Masyarakat}

Dari hasil observasi, sosialisasi dan diskusi kegiatan dengan aparatur pemerintah daerah setempat serta pengelola bank sampah dapat diidentifikasi berbagai aset yang dimiliki oleh rw 08 kelurahan air putih dalam pengelolaan sampah ini. Aset manusia yang dimiliki oleh rw 08 kelurahan air putih ini adalah perangkat rt dan rw yang aktif berperan dalam menggerakkan sumber daya. Selain itu, juga terdapat pengelola bank sampah yang aktif berkegiatan dalam pengelolaan sampah. Aset finansial yang teridentifikasi adalah adanya warga setempat yang bersedia menyediakan lokasi bank sampah. Aset sosial adalah adanya kegiatan pkk yang cukup aktif. Anggota pkk ini nantinya diharapkan bisa berkoordinasi dengan pengelola bank sampah dalam mengolah sampah anorganik yang terkumpul di bank sampah menjadi barang dekoratif dan kembali bisa dimanfaatkan serta bernilai ekonomi.

Dalam kegiatan sosialisasi dan diskusi tersebut juga teridentifikasi beberapa permasalahan yang dialami pengelola bank sampah dalam mengelola sampah dari nasabah antara lain keterlambatan pencairan dana nasabah oleh pengepul yang mengakibatkan menurunkan partisipasi nasabah untuk menyetorkan sampah ke bank sampah. Selain itu, kondisi pandemi Covid-19 yang tengah terjadi mengakibatkan dihentikannya sementara penjemputan sampah oleh pengepul sehingga terjadi penumpukan sampah di bank sampah. Adanya keterbatasan lokasi bank sampah menyebabkan pengelola bank sampah untuk menghentikan juga sementara waktu penerimaan sampah dari nasabah. Hal ini sangat berdampak pada perubahan perilaku nasabah sehingga saat bank sampah beroperasi kembali, jumlah nasabah yang menyetorkan sampah dan jumlah sampah yang diperoleh juga sangat jauh berkurang. Dari informasi pengelola bank sampah, saat operasional bank sampah tersebut diberhentikan sementara, nasabah mulai abai dalam memilah sampah. Apabila ini dibiarkan, perilaku masyarakat yang tadinya sudah mulai baik dalam pengelolaan sampah rumah tangga akan bisa kembali menjadi buruk lagi. 
Dalam hal pengolahan sampah anorganik yang telah terkumpul, pengelola bank sampah sudah pernah mencoba membuat kerajinan tangan dengan memanfaatkan kertas dan kardus bekas yang disetorkan oleh nasabah bank sampah, menjadi kotak tisu. Namun sampai saat diskusi ini dilaksanakan, hasil kerajinan tersebut masih disimpan oleh pengelola dan belum berhasil dipasarkan.

\section{Pelatihan Pengolahan Sampah Anorganik Menjadi Barang Dekoratif dengan Teknik Decoupage}

Pelatihan ini dilaksanakan dengan melibatkan pengelola Bank Sampah Berkah dan perwakilan PKK dari masing-masing RT sebagai peserta pelatihan. Jumlah peserta pelatihan dibatasi maksimal 10 orang, yang terdiri dari 6 orang pengelola Bank Sampah Berkah dan 4 orang perwakilan PKK masing-masing RT.

Pemilihan teknik decoupage ini dikarenakan cukup mudah untuk dikerjakan, tidak membutuhkan skill tertentu dan saat ini hasil seni dekoratif decoupage ini memiliki pasar yang cukup prospektif di tengah-tengah masyarakat dengan nilai jual yang relatif cukup tinggi. Pelatihan ini dimulai dengan pemaparan tentang teknik decoupage, bahan-bahan yang dibutuhkan, barang-barang apa saja yang bisa dihias dengan teknik decoupage ini, teknik dasar pengaplikasiannya serta permasalahan-permasalahan yang sering muncul dalam mengaplikasikan teknik decoupage dan solusi-solusinya.

Kegiatan pelatihan kemudian dilanjutkan dengan praktik langsung sehingga dapat dilihat kemampuan peserta dalam menghasilkan barang dekoratif dengan teknik decoupage ini. Dalam pelatihan ini, media yang digunakan untuk mengaplikasikan teknik decoupage ini adalah botol kaca, botol plastik, kaleng bekas karena barang-barang tersebut merupakan sampah anorganik yang cukup banyak terkumpul di bank sampah. Dalam pelatihan ini, peserta diajarkan bagaimana cara mengaplikasikan cat dasar pada media dengan permukaan licin dan daya serap rendah seperti botol kaca, botol plastik dan kaleng ini supaya dapat menghasilkan cat dasar yang baik dan rata. Selain itu, juga diajarkan trik penggunanaan lem pada saat menempelkan motif atau corak ke media pada media dengan permukaan licin ini. Dalam pelatihan ini, motif yang ditempelkan diambil dari tisu decoupage. Lapisan tisu yang sangat tipis beresiko tinggi untuk robek atau menggelembung saat ditempelkan apabila tidak dilakukan penempelan dengan teknik yang benar. Dengan adanya praktik langsung ini, peserta menjadi lebih paham bagaimana cara mengaplikasikan teknik tersebut dengan benar dan cara mengatasi permasalahan-permasalahan yang terjadi saat mengaplikasikan teknik decoupage, terutama pada pada media dengan permukaan licin yang memiliki tingkat kesulitan yang lebih tinggi dibandingkan media dengan permukaan kesat. Produk yang sudah dihasilkan oleh peserta pelatihan dapat dilihat pada gambar 1.

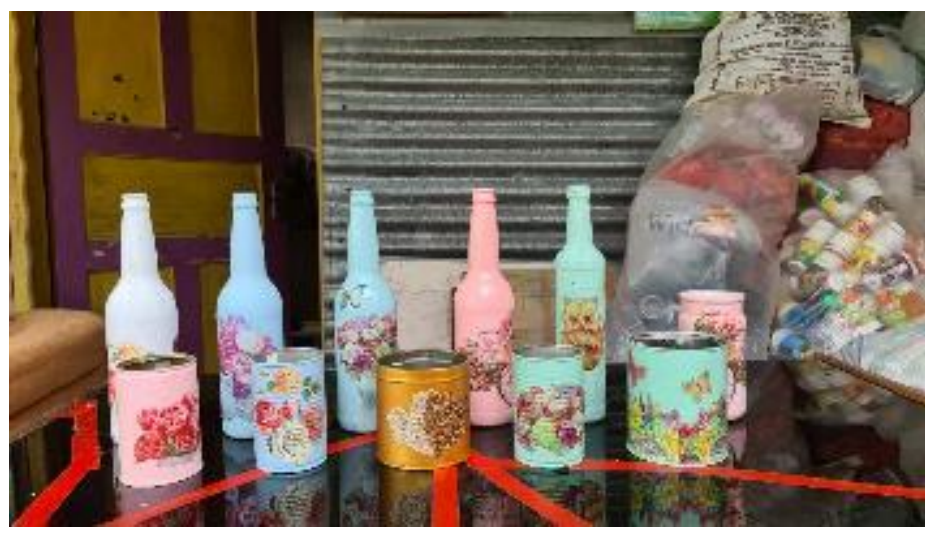

Gambar 1. Hasil kerajinan dengan mengaplikasikan teknik decoupage dengan memanfaatkan sampah anorganik seperti botol dan kaleng bekas.

\section{Pelatihan Pemasaran Produk dengan Memanfaatkan Media Sosial}

Selain mengajarkan teknik decoupage, tim pengabdian juga memberikan wawasan kepada peserta pelatihan bagaimana memasarkan produk yang telah dihasilkan pada waktu yang terpisah. Masyarakat sasaran pada kegiatan ini masih sama, yaitu pengelola Bank Sampah Berkah dan perwakilan PKK dari masing-masing RT. Pada umumnya peserta pelatihan telah memiliki media sosial seperti facebook, instagram dan whatsapp dan cukup terbiasa menggunakan media sosial tersebut. Dalam pelatihan ini, dipaparkan kelebihan dan kekurangan masing-masing media sosial bila digunakan dalam pemasaran produk, antara lain jangkauan pasarnya, dukungan fasilitas promosi usaha yang ada, biaya yang harus dikeluarkan dalam menggunakan platform tersebut hingga tingkat keamanan penggunaan saat dijadikan sebagai media pemasaran. Masing-masing dari media sosial memiliki keunggulan dan kelemahan sehingga dalam pelatihan ini, peserta disarankan untuk 
mengkombinasikan dua media sosial dimana salah satu memiliki keunggulan dari segi promosi, jangkauan pasar dan gratis seperti facebook dan instagram, sedangkan yang lainnya menawarkan fitur keamanan bertukar informasi dengan calon konsumen dan juga tidak berbayar seperti pada whatsapp bussiness. Selain itu, lintas komunikasi pada whatsapp business yang berbeda dengan jalur pribadi akan sangat membantu peserta pelatihan untuk memilah apakah pesan berasal dari calon konsumen atau bukan. Dari kegiatan ini, pengelola Bank Sampah Berkah dinilai telah memahami bagaimana memanfaatkan media sosial menjadi tempat pemasaran produknya dan mengatur jalur komunikasi dengan calon konsumen dengan menggunakan whatsapp business.

\section{Monitoring dan Evaluasi Ketercapaian Sasaran}

Hasil evaluasi kegiatan jangka pendek menunjukkan bahwa masyarakat target telah mampu mengaplikasikan teknik decoupage pada botol dan kelang bekas dan telah memahami bagaimana cara memanfaatkan media sosial yang ada dalam pemasaran produk yang dihasilkan. Hal ini dinilai dari sudah adanya produk yang dihasilkan dari pelatihan teknik decoupage ini dan sudah terbentuknya toko online Berkah Shop dengan nomor kontak whatsapp bussiness 085265662538 . Aplikasi whatsapp bussiness ini juga telah disinkronkan dengan media sosial facebook sebagai media promosi yang dapat diakses pada laman www.facebook.com/berkah.shop.rina.

Evaluasi jangka panjang belum bisa dinilai secara optimal dikarenakan saat ini yang baru bisa dinilai adalah kemandirian masyarakat target saja, namun keberlangsungan kegiatan dan nilai ekonomi yang dihasilkan masih belum bisa diukur dikarenakan kegiatan ini baru mulai dijalankan oleh masyarakat target.

Kemampuan mengolah kembali sampah anorganik ini tentu saja diharapkan tidak saja dimiliki oleh pengelola bank sampah, namun juga pada masyarakat pada umumnya sehingga jumlah sampah yang dihasilkan akan semakin dapat diminimalisir dan tidak menutup kemungkinan dapat memberikan pemasukan ekonomi tambahan bagi masyarakat. Dari analisis tim pengabdian, diperkirakan biaya produksi yang diperlukan untuk menghasilkan satu kerajinan decoupage berkisar 7.500-20.000 rupiah, tergantung besarnya ukuran, tingkat kerumitan dan banyaknya tissue decoupage yang digunakan. Sementara nilai jual produk diperkirakan berkisar 30.000-150.000 rupiah, dengan mengacu kepada rata-rata harga pasar hasil kerajinan decoupage yang ada. Semakin rumit teknik yang digunakan harga produk juga akan semakin mahal.

Kondisi pandemi covid-19 menyebabkan kuantitas masyarakat target yang dapat dilatih menjadi sangat terbatas. Semakin banyak masyarakat di lingkungan RW 08 Kelurahan Air Putih yang mampu mengaplikasi teknik decoupage, maka barang dekoratif yang dihasilkan dengan memanfaatkan sampah anorganik yang terkumpul di Bank Sampah Berkah akan menjadi lebih banyak. Hasil penjualannya tentu saja akan memberikan manfaat lebih bagi nasabah bank sampah tersebut dibandingkan dengan hanya menjual dalam bentuk sampah ke pengepul. Saat ini sumber daya manusia yang telah dilatih yang menunjukkan minat dan keseriusan menghasilkan kerajinan decoupage dengan memanfaatkan sampah anorganik ini masih terbatas pada pengelola Bank Sampah Berkah yang berjumlah enam orang. Pengelola bank sampah inilah yang diharapkan dapat menjadi perpanjangan tangan tim pengabdian untuk mengajarkan kembali teknik decoupage ini dan menstimuli warga di sekitar untuk ikut mengolah sampah anorganik rumah tangga menjadi barang dekoratif ini.

\section{KESIMPULAN}

Berdasarkan uraian di atas dapat disimpulkan bahwa secara kualitas masyarakat target telah mampu mengolah sampah anorganik yang terkumpul menjadi barang dekoratif yang dapat dimanfaatkan kembali dan bernilai jual lebih tinggi dengan mengaplikasikan teknik decoupage. Selain itu masyarakat target juga telah memahami bagaimana teknik pemasaran dengan memanfaatkan media sosial yang ada. Meskipun masyarakat target dinilai telah mandiri dalam menghasilkan produk pengolahan sampah anorganik ini, namun keberlangsungan kegiatan ini masih perlu dievaluasi lebih lanjut. Keterbatasan sumber daya manusia juga dapat menjadi kendala dalam keberlangsungan produksi. Perluasan target pelatihan serta dukungan lebih lanjut dari aparatur pemerintah setempat sangat diperlukan untuk keberlangsungan usaha masyarakat ini.

\section{UCAPAN TERIMA KASIH}

Ucapan terima kasih disampaikan kepada pimpinan Universitas Riau yang telah memberikan dukungan moril dan materil dalam pelaksanaan kegiatan pengabdian kepada masyrakat ini. Kegiatan ini didanai dari Hibah Pengabdian kepada Masyarakat dengan Skema Desa Binaan Universitas Riau tahun 2020. 


\section{DAFTAR PUSTAKA}

Anggoro, F.B. 2017. 1260 Ton Limbah Plastik Dihasilkan Kota Pekanbaru dalam Satu Bulan. Antarariau.com, 2 Agustus 2017. Diakses dari https://riau.antaranews.com/berita/92272/1260-ton-limbah-plastik pada 13 juli 2020

Mallapiang, F., Kurniati, Y., Syahrir, S., Lagu, A.M.H.R., Sadarang, R.A.I. 2020. Pengelolaan Sampah dengan Pendekatan Asset Bases Community Development (ABCD) di Wilayah Pesisir Bulukumba Sulawesi Selatan. Riau Journal of Empowerment, 3(2), 79-86. https://doi.org/1031258/raje.3.2.79-86.

Mardhia, D., Wartiningsih, A. 2018. Pelatihan Pengolahan Sampah Skala Rumah Tangga di Desa Penyaring. Jurnal Pendidikan dan Pengabdian Masyarakat, 1(1), 88-96. https://jurnalfkip.unram.ac.id/index.php/JPPM/article/view/492

Riswan, Sunoko, H.R., Hadiyarto, A. 2011. Pengelolaan Sampah Rumah Tangga di Kecamatan Daha Selatan. Jurnal Ilmu Lingkungan, 9(1), 31-38. https://doi.org/10.14710/jil.9.1.31-38.

Subekti, S. 2018. Pengelolaan Sampah Rumah Tangga 3R Berbasis Masyarakat. Dalam Prosiding Seminar Nasional Sains dan Teknologi.

Susilawaty, A., Nurdiyanah, Aryadin, A. 2018. Identifikasi Aset Sarana Sanitasi Dasar dengan Pendekatan Asset Based Community Development (ABCD) di Desa Barugaia Kecamatan Bontomanai Kabupaten Pulau Selayar. Alsihah: Public Health Science Journal, 10(1), 96-107. https://journal.uin-alauddin.ac.id/index.php/Alsihah/article/view/5423.

Susilowati, L.E. 2014. Peran Perempuan dalam Pengelolaan Sampah Rumah Tangga Berbasis Program 4P di Wilayah Pesisir Desa Labuhan Haji Lombok Timur. Jurnal Penelitian Unram, 18, 96-105. 